\title{
Six Sigma Implementation to reduce rejection rate of Pump Casings at local Manufacturing Company
}

\author{
Faheem Yousaf ${ }^{1}$, Dr. Shahid Ikramullah Butt ${ }^{1}$, Dr. Riaz Ahmad ${ }^{1}$ \\ ${ }^{1}$ National University of Science and Technology, Islamabad, Pakistan
}

\begin{abstract}
Six Sigma is being Implemented all over the World as a successful Quality Improvement Methodology. This article provides a description of Six Sigma Project implemented at Local manufacturing Company. The Company Manufactures Pump Casings where it was receiving high nonconformance rate that resulted in to Rejection of Product. This study deals with Six Sigma DMAIC methodology implementation and gives a frame work of how the non-conformance rate was first monitored and then brought in to acceptance limits. A complete Coverage of the statistical analysis performed during the study is given and results are shown to describe that how Six Sigma helped the Project members to Improve Quality of Pump casings at manufacturing facility.
\end{abstract}

Keywords: Statistical Process Control (SQC), Process Capability Indices, Six Sigma, Variable control chart, Pareto charts, Standard deviation, Critical to Quality (CTQ), Analysis of Variance (ANOVA), DMAIC, Total quality Management (TQM)

\section{Introduction}

In this Era of changing customer needs and demand of highly reliable products have pushed many manufacturing companies to adopt Total Quality Management (TQM) principles. Globalization and extension of Product Market has also increased the need of Quality Products at Reasonable cost to Customers. To respond to these Demands many Companies are implementing different Quality Management Principles at their manufacturing facilities such as ISO 9000, Just in Time (JIT), Lean Manufacturing, and Kaizan etc. A new and Improved Quality Improvement Approach called Six Sigma is also becoming Popular in Controlling the Defect rate and managing the Quality as overall Process Function.

The roots of Six Sigma as a measurement standard can be traced back to Carl Frederick Gauss (17771855) who introduced the concept of the normal curve. Six Sigma as a measurement standard in product variation can be traced back to the 1920's when Walter Shewhart showed that three standard deviations from the process mean is the point where a process requires correction. Many measurement standards (Zero defects etc.) Later came on the scene but credit for coining the term "Six Sigma" goes to a Motorola engineer named Bill Smith. (Incidentally, "Six Sigma" is a federally registered trademark of Motorola).

In the early and mid-1980s with Chairman Bob Galvin, Motorola engineers decided that the traditional quality levels; measuring defects in thousands of opportunities didn't provide enough granularity. Instead, they wanted to measure the defects per million opportunities. Motorola developed this new standard and created the methodology and needed cultural change associated with it. Since then, hundreds of companies around the world have adopted Six Sigma as a way of doing business.

\section{Overview of Statistical Quality Control (SQC)}

Quality may be defined as that characteristic which Renders a product or service as having "fitness for Purpose or use". There are different reasons why a Product may have poor quality. Statistical Methods play a central role in Quality improvement Efforts and recognized as an efficient and powerful tool in dealing with the process control aspects (Montgomery 2003).

Statistical Quality Control (SQC) is the term used to describe the set of statistical tools used by quality professionals. SQC is used to analyze the quality problems and solve them. Statistical quality control refers to the use of statistical methods in monitoring and maintaining of the quality of products and services. All the tools of SQC are helpful in evaluating the quality of services. SQC uses different tools to analyze quality problems. Descriptive Statistics, Statistical Process Control (SPC) and Acceptance Sampling are the major SQC Techniques used in Improving Quality of Processes.

\subsection{Concept of Variation}

Variation is part and parcel of life. The concept of Variation states that no two products will be perfectly identical even if extreme care is taken to make them Identical in some aspect. The variation in the quality of Product in any manufacturing process results because of two reasons namely, Chance cause and 
Assignable Cause. A process that is operating with only chance causes of variation is said to be in a state of control with minor variations in the process. The major objective of SPC is to quickly detect the occurrence of assignable causes so that investigation of process and corrective action may be taken before many nonconforming units are manufactured. Finally the eventual goal of SPC is the elimination of variability in the processes.

\subsection{Process Capability}

The Process Capability studies are helpful in analyzing the quality and efficiency of the process. The Process Capability analysis has been widely adopted as the ultimate measure of Performance to evaluate the ability of a process to satisfy the customers in the form of specifications (English et al 1993).

The Process Capability study helps in designing the product, deciding the acceptance limits of the process and operators in the operations management (Feigenbaum 1994). The evaluation of process capability is an important step in process quality improvement (Juran 1991). It is customary to take the Six Sigma Prime spread in the distribution of the product Quality Characteristic as a measure of process capability. In Process Capability study of particular process, Six Sigma Prime spread is compared with the difference of Upper Specification Limit (USL) and the Lower Specification Limit (LSL). The following are the three possible cases.

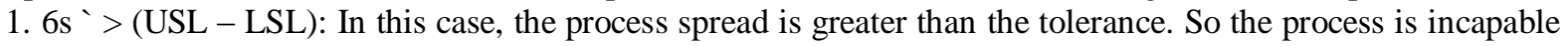
of meeting the Specification.

$2.6 s^{`}=(\mathrm{USL}-\mathrm{LSL})$ : In this case, the process spread is exactly equal to the tolerance. So the process is exactly capable of meeting the specifications.

3. $6 s^{\prime}<(\mathrm{USL}-\mathrm{LSL})$ : In this case, the process spread is less than the tolerance. So the process is capable of meeting the specifications.

\subsection{Process Capability Indices}

It is frequently convenient for Engineers to have a simple and quantitative way to express process capability. One way to do so is through process capability indices. Process capability indices (PCI) are powerful means of studying the process ability for manufacturing a product that meets specifications (Chen et al 2001). PCI is defined as the ratio of tolerances to the process spread. Equation (1) describes the way to calculate PCI.

Process Capability Index $(\mathrm{PCI})=(\mathrm{USL}-\mathrm{LSL}) / 6 \mathrm{~s}$

Where PCI is process Capability indices, USL is upper specification limit, LSL is lower specification limit and $6 \mathrm{~s}$ is the six sigma abbreviation.

\subsection{Six Sigma}

It is the set of practices originally developed by Motorola to systematically improve process by eliminating defects. Defect is defined as non-conformity of a product or service to its specification. Like its previous quality improving methodologies six sigma focuses on the following points.

- A continuous effort to reduce variation in process outputs is essential to business success.

- Manufacturing and business processes can be Measured, Analyzed, Improved and Controlled.

- In order to achieve best Quality Improvement results, role of upper management is very critical.

The term Six Sigma refers to a highly capable process that can produce products within specifications. Process that achieves Six Sigma levels produces only 3.4 defective Products per million opportunities. Main focus of Six Sigma is to improve all key processes of manufacturing setup and takes quality as a function of Processes Capability to produce items with in specification.

Six Sigma mainly uses two main methodologies one is called Define, Measure, Analyze, Improve and Control, usually known as DMAIC and other is Define, Measure, Analyze, Design and Verify, known as DMADV. Both the methodologies are based on Edwards Deming's, Plan-

DMADV is used for creating new processes to produce products with minimum defect rate.

Other methodologies that are being used during six sigma implementation are given as.

- DCCDI (Define, Customer, Concept, Design And Implement)

- CDOC (Conceptualize, Design, Optimize and Control)

- DCDOV (Define, Concept, Design, Optimize and Verify)

- DMADOV (Define, Measure, Analyze, Design, Optimize and Verify)

- DMEDI (Define, Measure, Explore, Develop and Implement)

- IDOV (Identify, Design, Optimize and validate)

- IIDOV (Invent, Innovate, Develop, Optimize and validate) 
DMAIC methodology has been used as effective methodology in before mentioned organization; details of this methodology are given as.

\subsection{Define, Measure, Analyze, Improve and Control (DMAIC)}

Basically this methodology comprises of following five key points.

- Define the process improvement goals that are aligned with the customer demands and company's strategy.

- Measure the current process and make a strategy for making further improvement.

- Analyze to verify the relationship and causality of factors. Determine what the relationship is and attempts to ensure that all the factors have been considered.

- Improve and optimize process based on findings of analysis phase using different techniques.

- Control to ensure that any variances are corrected before they result in defects.

\subsection{DMAIC Implementation at Pump Casing manufacturing company}

DMAIC is chosen as potential methodology for implementation at pump casings manufacturing company. At this company quality management systems like ISO 9000 are already implemented that's why quality improvement focus is to only reduce nonconformities. Figure 1 describes the five phases of DMIAC that are implemented at manufacturing facility with different statistical techniques.

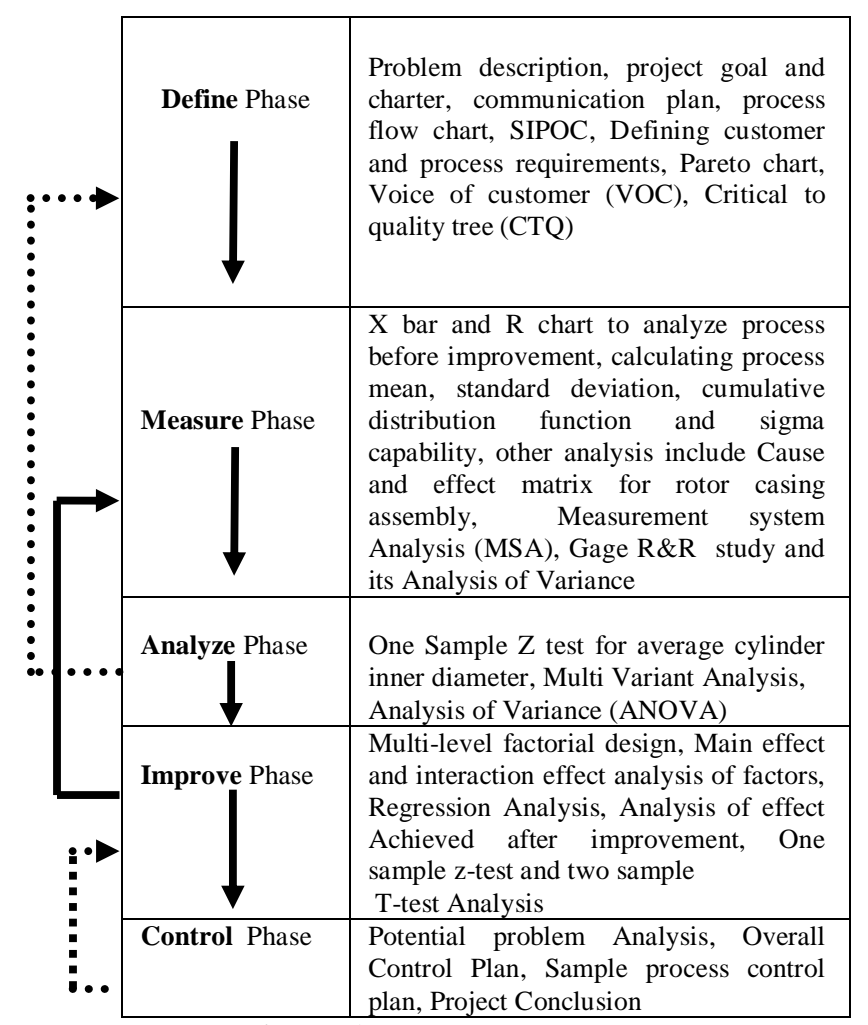

Figure 1. DMAIC Flow Chart

\section{Define Phase}

It is the first stage of Six Sigma DMAIC project, the phase determines the objectives and scope of the project and it defines the problem \& communicates the problem to others.

\subsection{Problem Description}

Company $\mathrm{ABC}$ is a manufacturing organization that produces pump casings and different subassemblies related to Pump. For the few weeks company is receiving high rejection rate in pump casings, this results in high rework rate and due to which higher production time is spent and also credibility of the company and profits are being affected.

Approximately $25 \%$ pump casings produced by manufacturing facility are either required to be reworked or rejected at final inspection (Rework and rejection are both considered as defects), this was found when the last two lots were sampled for inspection. 


\subsection{Project Goal and Charter}

Management of the company wanted a detail process study of different sections of manufacturing Facility. For this purpose a project team was made whose primary responsibility was to identify the key factors playing role in rejection and rework and then to take certain improvement measures to reduce the rejection rate. Table 1 clearly defines the Project Team Charter. Clearly the project goal is to reduce Current rejection rate from $25 \%$ to $1 \%$ (acceptance limit).

Table 1. Project Team Description

\begin{tabular}{|c|c|c|}
\hline \multicolumn{3}{|c|}{ Project Team Charter } \\
\hline \multicolumn{2}{|c|}{ Team Members Status } & Involvement in Project \\
\hline \multicolumn{2}{|c|}{ Sponsor and Champion } & $\begin{array}{l}\text { Define, Project Charter, } \\
\text { Project Closure }\end{array}$ \\
\hline \multicolumn{2}{|c|}{ Black Belt } & Project Implementation \\
\hline \multicolumn{2}{|c|}{ Production Department } & Improve and Control \\
\hline \multicolumn{2}{|c|}{ Quality control Head } & Data collection and Analysis \\
\hline \multicolumn{3}{|c|}{$\begin{array}{l}\text { Project Title: Implementation of Six Sigma to reduce rejection } \\
\text { rate of Pump Casings. } \\
\text { Subject Matter Experts: Black Belt, Champion Six Sigma. } \\
\text { Stake Holders: Employees of Company, Production } \\
\text { Department, and quality control Department. }\end{array}$} \\
\hline \multicolumn{3}{|c|}{ Project Milestones } \\
\hline S.NO. & \multicolumn{2}{|l|}{ PHASE } \\
\hline 1 & \multicolumn{2}{|l|}{ Define } \\
\hline 2 & \multicolumn{2}{|l|}{ Measure } \\
\hline 3 & \multicolumn{2}{|l|}{ Analyze } \\
\hline 4 & \multicolumn{2}{|l|}{ Improve } \\
\hline 5 & \multicolumn{2}{|l|}{ Control } \\
\hline
\end{tabular}

\subsection{Communication Plan for DMAIC Project}

Table 2 shows the complete communication plan for Project.

Table 2. Communication Plan for Six Sigma Project

\begin{tabular}{|l|l|l|l|l|l|}
\hline What & $\begin{array}{l}\text { To } \\
\text { whom }\end{array}$ & When & Who & How & Where \\
\hline $\begin{array}{l}\text { Project } \\
\text { meetings }\end{array}$ & $\begin{array}{l}\text { Project } \\
\text { team } \\
\text { invitees }\end{array}$ & $\begin{array}{l}\text { Every } \\
\text { Thursday }\end{array}$ & $\begin{array}{l}\text { Black } \\
\text { belt }\end{array}$ & $\begin{array}{l}\text { Via } \\
\text { mail }\end{array}$ & $\begin{array}{l}\text { Conference } \\
\text { room }\end{array}$ \\
\hline $\begin{array}{l}\text { Minutes of } \\
\text { meetings }\end{array}$ & $\begin{array}{l}\text { Distribu } \\
\text { tion list }\end{array}$ & $\begin{array}{l}\text { Next day of } \\
\text { meeting }\end{array}$ & $\begin{array}{l}\text { Black } \\
\text { belt }\end{array}$ & $\begin{array}{l}\text { Via } \\
\text { mail }\end{array}$ & $\begin{array}{l}\text { Office of black } \\
\text { belt }\end{array}$ \\
\hline Team work & $\begin{array}{l}\text { Project } \\
\text { team }\end{array}$ & $\begin{array}{l}\text { As per } \\
\text { requiremen } \\
\text { t }\end{array}$ & $\begin{array}{l}\text { Black } \\
\text { Belt }\end{array}$ & $\begin{array}{l}\text { Via } \\
\text { mail }\end{array}$ & $\begin{array}{l}\text { Office of black } \\
\text { belt }\end{array}$ \\
\hline Status reports & $\begin{array}{l}\text { Custom } \\
\text { er }\end{array}$ & $\begin{array}{l}\text { Every } \\
\text { Friday }\end{array}$ & $\begin{array}{l}\text { Black } \\
\text { Belt }\end{array}$ & $\begin{array}{l}\text { Via } \\
\text { mail }\end{array}$ & $\begin{array}{l}\text { Office of black } \\
\text { belt }\end{array}$ \\
\hline
\end{tabular}

\subsection{SIPOC for Pump Casings}

Supplier, Inputs, Processes, Outputs, Customers i.e. SIPOC is a process improvement and analysis tool that summarizes the input and output of one or more processes. This tool helps to sum up the inputs and outputs of a certain process according to the customer point of view that helps to analyze the requirements of each process in one table format.

For the current facility the SIPOC is shown in Table 3. From the current system study it was revealed that Pump casings key supplier is material store accompanied with manufacturing shops. Inputs to the process are manufacturing process parameters and piece of bars in rectangular and cylindrical form. Complete process details and outputs along with customers are shown in Table 3. 
Table 3. SIPOC for Pump Casing

\begin{tabular}{|c|c|c|c|c|}
\hline Suppliers & Inputs & Processes & Outputs & Customers \\
\hline $\begin{array}{l}\begin{array}{l}\text { Material } \\
\text { store }\end{array} \\
\text { Welding } \\
\text { section, } \\
\text { Milling } \\
\text { section, }\end{array}$ & $\begin{array}{l}\text { Piece of round/ } \\
\text { rectangular bar, } \\
\text { Tool angle, } \\
\text { Tool, } \\
\text { Feed, } \\
\text { Depth of cut, } \\
\text { Coolant flow }\end{array}$ & $\begin{array}{l}\text { Facing, } \\
\text { Turning, } \\
\text { Taper turning, } \\
\text { Boring, } \\
\text { Threading, } \\
\text { Milling, } \\
\text { Drilling, } \\
\text { Welding, } \\
\text { Assembly. }\end{array}$ & $\begin{array}{l}\text { Rotor cylinder, } \\
\text { Pads with holes, } \\
\text { Padded Rotor } \\
\text { cylinder, } \\
\text { Nozzle end, } \\
\text { Front Stopper, } \\
\text { Chuck } \\
\text { Ring, } \\
\text { Hexagonal } \\
\text { section of nozzle } \\
\text { end, } \\
\text { Assembled rotor } \\
\text { casings }\end{array}$ & $\begin{array}{l}\begin{array}{l}\text { Inspection and } \\
\text { quality } \\
\text { department, }\end{array} \\
\text { Assembly } \\
\text { section, } \\
\text { Manufacturing } \\
\text { shops, } \\
\text { End users }\end{array}$ \\
\hline
\end{tabular}

\subsection{Process flow chart for Pump casings}

Complete flow chart of the manufacturing process at manufacturing facility of pump casings was developed and shown in Figure 2. This chart provides good understanding of process and material flow.

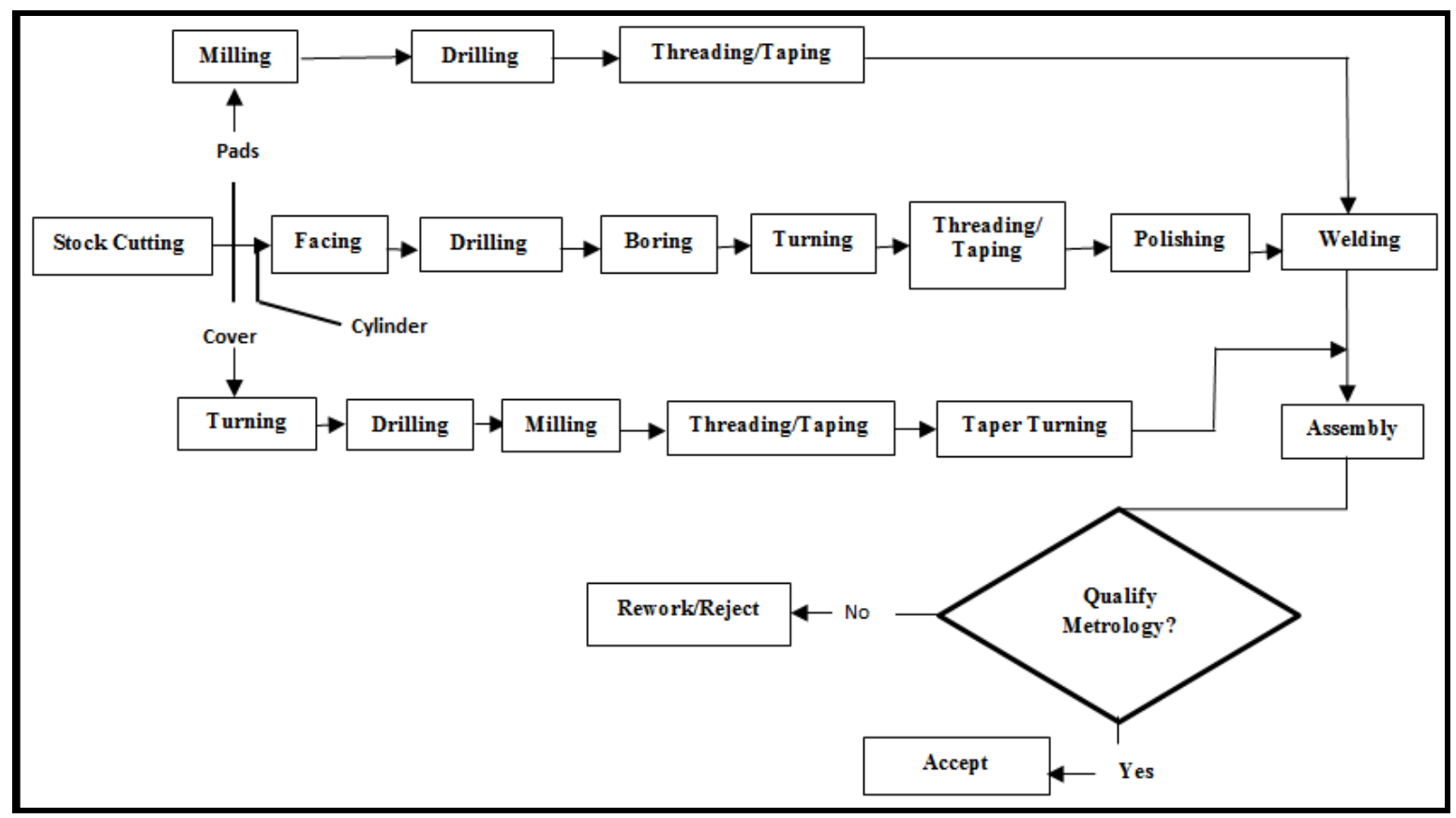

Figure 2. Pump Casing's Process Flow Chart

\subsection{Defining Process boundaries and customer Rrequirements}

Main manufacturing processes are setup to process three items named as cover, cylinder and pads. Complete flow diagram is illustrated in Figure 3. According to detailed study of the processes it was revealed that chamber inner diameter, nozzle throat diameter and some other defects were contributing to high nonconformance rate . Figure 3 shows a Pareto chart which summarizes the key defects in process outputs, this show that chamber Inner Diameter accounts for $71.4 \%$ of total defects and comes to be potential Key Process Input Variables (KPIV) to be addressed. 


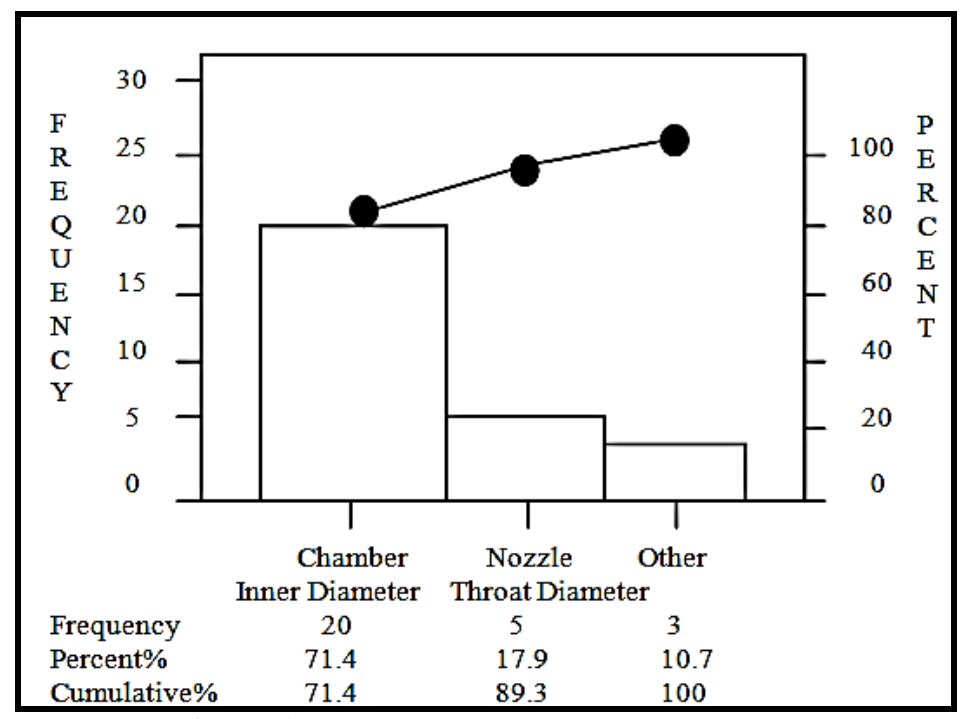

Figure 3. Pareto chart for defects monitoring

Customer data i.e. Voice of Customer (VOC) revealed that internal customers are being affected by the defects rate of Chamber inner diameter that accounts for major portion of defects as explained in Figure 3. Thus Critical To Quality (CTQ) tree can be established based on voice of customer and project objectives. Figure 4 shows the CTQ tree based on the voice of customer

\begin{tabular}{|c|c|c|}
\hline Needs & CTQ's & HOW? \\
\hline $\begin{array}{l}\text { Improve Pump } \\
\text { Casings Quality, } \\
\text { Reduce } \\
\text { Rework/Rejection }\end{array}$ & $\begin{array}{l}\text { Reduce } \\
\text { chamber inner } \\
\text { diameter } \\
\text { defects by } \\
\text { improving the } \\
\text { Process } \\
\text { reliability and } \\
\text { reducing } \\
\text { variations. }\end{array}$ & $\begin{array}{l}\text { Study Complete Production } \\
\text { Process, Identify Critical Factors } \\
\text { effecting Quality and Address } \\
\text { them, Benchmark Quality Level } \\
\text { to be Attained, Analyze all the } \\
\text { Processes In detail, Make } \\
\text { changes Suggested by Quality } \\
\text { Experts, Implement Changes and } \\
\text { Control the Processes with made } \\
\text { changes, Finally Monitor results } \\
\text { to validate Quality Improvement. }\end{array}$ \\
\hline
\end{tabular}

Figure 4. Critical To Quality (CTQ) Tree

\section{Measure Phase}

The primary requirement of this phase is the complete process map of manufacturing process that is given in Figure 2 of define phase. Measure Phase focuses on the following points about Six Sigma Project.

\subsection{Determines What to Measure}

The Six Sigma project team needs to come out with an explicit list of vital inputs, desired outputs and process metrics that they are planning to track. This decision has large scale implications on the performance of the project and is usually taken by the Project Leader on the basis of data provided by the Six Sigma team and the Process Owner.

\subsubsection{Determine How to Measure}

There have been many cases of measurement bias in Six Sigma history. The bias may have its roots in the complexity of the calculation, the wrong method of data collection or the bias of the person performing the exercise.

\subsubsection{Manage the Measurement Process}

One of the biggest challenges of this phase is to validate the fact that the measurement system in place is good for the purpose. This challenge has been discussed in detail in the section titled Measurement Systems Analysis. 


\subsubsection{Calculating the Current Sigma Levels}

A common practice in the measure phase is to put a figure in front of the losses that the organization is currently facing due to inefficient processes. This helps the management to evaluate the process and the Six Sigma team can bargain for more resources to successfully implement the project.

\subsection{Current Base line for the Process}

Mean of cylinder inner diameter $=50.4512 \mathrm{~mm}$

Standard deviation $=0.0708445 \mathrm{~mm}$

Upper specification limit $=50.6 \mathrm{~mm}$

lower specification limit $=50.4 \mathrm{~mm}$

\subsubsection{Cumulative Ddistribution Function of sample taken}

Normal with mean $=50.4512 \mathrm{~mm}$ and standard deviation $=0.0708445 \mathrm{~mm}$.

Cumulative Distribution Function

$$
\begin{array}{ll}
\mathbf{x} & \mathbf{P}(\mathbf{X}<=\mathbf{x}) \\
50.4 & 0.234929 \\
50.6 & 0.982152
\end{array}
$$

\subsubsection{Defective parts per million opportunities (DPPMO)}

Equation 2 gives us the formula to calculate defective parts per million opportunities.

DPPMO $=(\%$ of parts less than 50.4$)+(\%$ of parts greater than 50.6$) / 1,000000$

Using Equation 2 the defect percentage is calculated as.

$=(0.234929)+(1-0.982152) / 1000000$

$=252,777$

$=25.27 \%$

\subsubsection{Inverse Cumulative Distribution function}

Normal with mean $=0$ and standard deviation $=1$

\section{Inverse Cumulative Distribution Function}

$$
\begin{array}{cc}
\mathbf{P}(\mathbf{X}<=\mathbf{X}) & \mathbf{X} \\
0.252777 & -0.665776
\end{array}
$$

Measure of distance from the mean of sample (Z-score) is calculated to be $=0.665776$

Process Capability index (Cpk) is calculated to be

$=0.665776 / 3$

$=0.2219$

Sigma capability $=$ Z-score +1.5

Using equation 3 sigma capability for current process before improvement is calculated to be $=2.16$

\subsection{Cause and Effect matrix for Pump casing Assembly}

Cause and effect matrix for pump casings was made in detail and relationship between process inputs and outputs is described. From Table 4 it is clear that depth of cut, feed rate and tool angle are the important factors affecting the quality of pump casings. 
Table 4. Cause and Effect Matrix (C\&E)

\begin{tabular}{|c|l|l|l|l|l|l|l|l|l|}
\hline $\begin{array}{c}\text { Rating of } \\
\text { Iimportance to } \\
\text { Customers }\end{array}$ & $\mathbf{7}$ & $\mathbf{8}$ & $\mathbf{8}$ & $\mathbf{7}$ & $\mathbf{7}$ & $\mathbf{9}$ & $\mathbf{9}$ & $\mathbf{9}$ & \\
\hline S/N & $\mathbf{1}$ & $\mathbf{2}$ & $\mathbf{3}$ & $\mathbf{4}$ & $\mathbf{5}$ & $\mathbf{6}$ & $\mathbf{7}$ & $\mathbf{8}$ & \\
\hline Process output & A & B & C & D & E & F & G & H & Total \\
\hline $\begin{array}{l}\text { Process } \\
\text { input }\end{array}$ & 9 & 9 & 9 & 9 & 9 & 9 & 9 & 9 & 576 \\
\hline Depth of cut & 0 & 0 & 3 & 3 & 3 & 3 & 3 & 3 & 147 \\
\hline Feed & 1 & 3 & 1 & 3 & 3 & 3 & 1 & 3 & 144 \\
\hline Tool Angle & 1 & 3 & 1 & 1 & 1 & 3 & 1 & 1 & 98 \\
\hline Tool & 1 & 1 & 1 & 3 & 3 & 1 & 1 & 1 & 92 \\
\hline Speed & 0 & 1 & 1 & 1 & 1 & 3 & 1 & 1 & 75 \\
\hline Coolant Flow & 1 & 1 & 1 & 1 & 1 & 1 & 1 & 1 & 64 \\
\hline Material Type & & & & & & & & \\
\hline
\end{tabular}

Where $\mathrm{A}=$ cylinder length, $\mathrm{B}=$ cylinder inner diameter, $\mathrm{C}=$ cylinder wall thickness, $\mathrm{D}=$ cylinder front prepped, $\mathrm{E}=$ cylinder rear prepped, $\mathrm{F}=$ Nozzle throat Diameter, $\mathrm{G}=\mathrm{D}$-Nozzle Outer diameter, $\mathrm{H}=\mathrm{D}$-Nozzle angle.

\subsection{Measurement System Analysis [MSA]}

The next step in measurement phase is measurement system analysis. Basic measurement tool is Venire caliper. Two measurement analysis techniques named Gage Linearity and bias Study and Gage R and $r$ study were used and details are given.

\subsubsection{Control Charts}

In statistical process control XBar and $\mathrm{R}$ charts are type of control charts that are used to monitor samples data when data is collected at different intervals. Usually standard Deviations are monitored by Range chart commonly known as $\mathrm{R}$ chart and sample mean is monitored by X-bar chart.

In Figure 5 the XBar-R chart shows that process is out of control with maximum observations out of limits. Also a certain pattern is followed by the data points which may be due to machine error or operators shift change. Reasons of out of Control manufacturing process are given in Analyze Phase of the Project.

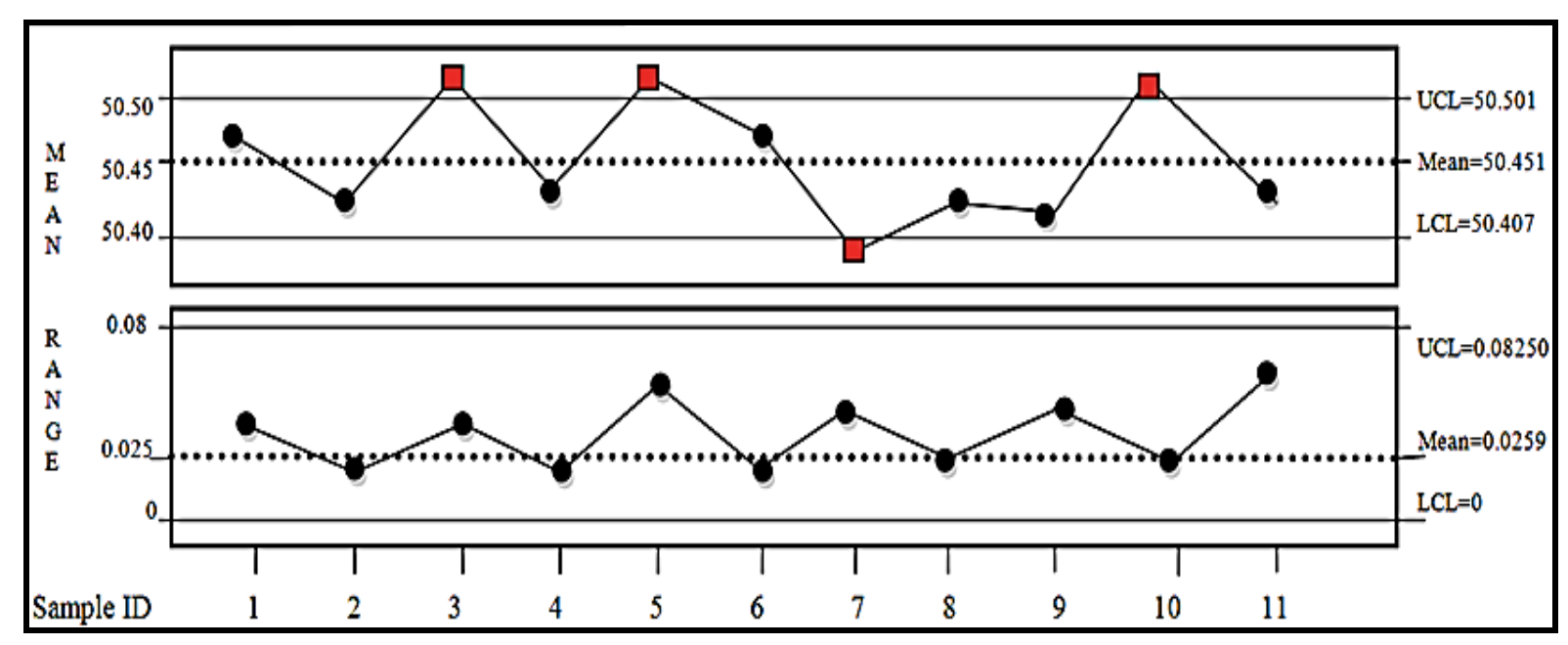

Figure 5. Xbar-R chart of cylinder inner Diameter before improvement 
Table 5. Gage Linearity Analysis

\begin{tabular}{lccc}
\hline Predictor & Coefficient & SE Coefficient & P \\
\hline Constant & 0.01434 & 0.01442 & 0.324 \\
Slope & 0.0000145 & 0.0001223 & 0.906 \\
S & 0.070711 & R-sq & $0.0 \%$ \\
Linearity & 0.0000051 & \%Linearity & 0.0 \\
\hline
\end{tabular}

Table 6. Gage Biasness Analysis

\begin{tabular}{lcll}
\hline Reference & Bias & \% Bias & P \\
\hline Average & 0.0156667 & 4.4 & 0.017 \\
1.5 & -0.031666 & 8.9 & 0.445 \\
25 & 0.0675000 & 19.1 & 0.004 \\
80 & 0.0125000 & 3.5 & 0.006 \\
150 & 0.0216667 & 6.1 & 0.012 \\
200 & 0.0083333 & 2.4 & 0.001 \\
\hline
\end{tabular}

Results shown in Table 5 and 6 provides enough evidence that bias of the instrument is constant over its measuring range and the gage measures constantly regardless of the part size.

\subsection{Gage Repeatability and Reproduce ability (R\&R) Study-ANOVA Method}

Another study of the measurement system was made by analysis of variance of gage. Complete data of the analysis is Table 7 and 8.

Table 7. Two-Way ANOVA Table with Interaction

\begin{tabular}{lcclcc}
\hline Source & DF & \multicolumn{1}{c}{ SS } & \multicolumn{1}{c}{ MS } & F & P \\
\hline Part ID & 9 & 1.4244 & 0.158271 & 2347.9 & 0.00 \\
Operator & 1 & 0.00003 & 0.0000 & 0.4 & 0.54 \\
Part ID*Operator & 9 & 0.00061 & 0.000067 & 2.25 & 0.03 \\
Repeatability & 40 & 0.0012 & 0.000030 & & \\
Total & 59 & 1.42627 & & & \\
\hline
\end{tabular}

Table 8. Gage R\&R Analysis

\begin{tabular}{|c|c|c|c|c|}
\hline Source & VarComp & $\% \mathrm{Cc}$ & \multicolumn{2}{|c|}{$\%$ Contribution (Varcomp) } \\
\hline Total Gage R\&R & 0.000042 & & 0.16 & \\
\hline Repeatability & 0.000030 & & 0.11 & \\
\hline Reproducibility & 0.000012 & & 0.05 & \\
\hline Operator & 0.000000 & & 0.00 & \\
\hline Operator*Part ID & 0.000012 & & 0.05 & \\
\hline Part-To-Part & 0.026367 & & 99.84 & \\
\hline Total Variation & 0.026409 & & 100.0 & \\
\hline Source & St Dev & $\begin{array}{c}\text { Study } \\
\text { Variation }\end{array}$ & $\begin{array}{l}\text { \% study } \\
\text { Variation }\end{array}$ & Tolerance \\
\hline Total Gage R\&R & 0.006517 & 0.033562 & 4.01 & 6.71 \\
\hline Repeatability S & 0.005477 & 0.028208 & 3.37 & 5.64 \\
\hline Reproducibility & 0.003531 & 0.018186 & 2.17 & 3.64 \\
\hline Operator & 0.00000 & 0.00000 & 0.0 & 0.00 \\
\hline Operator*Part ID & 0.003531 & 0.018186 & 2.17 & 3.64 \\
\hline Part-To-Part & 0.16238 & 0.836257 & 99.92 & 167.25 \\
\hline Total Variation & 0.162511 & 0.836931 & 100.0 & 167.39 \\
\hline
\end{tabular}




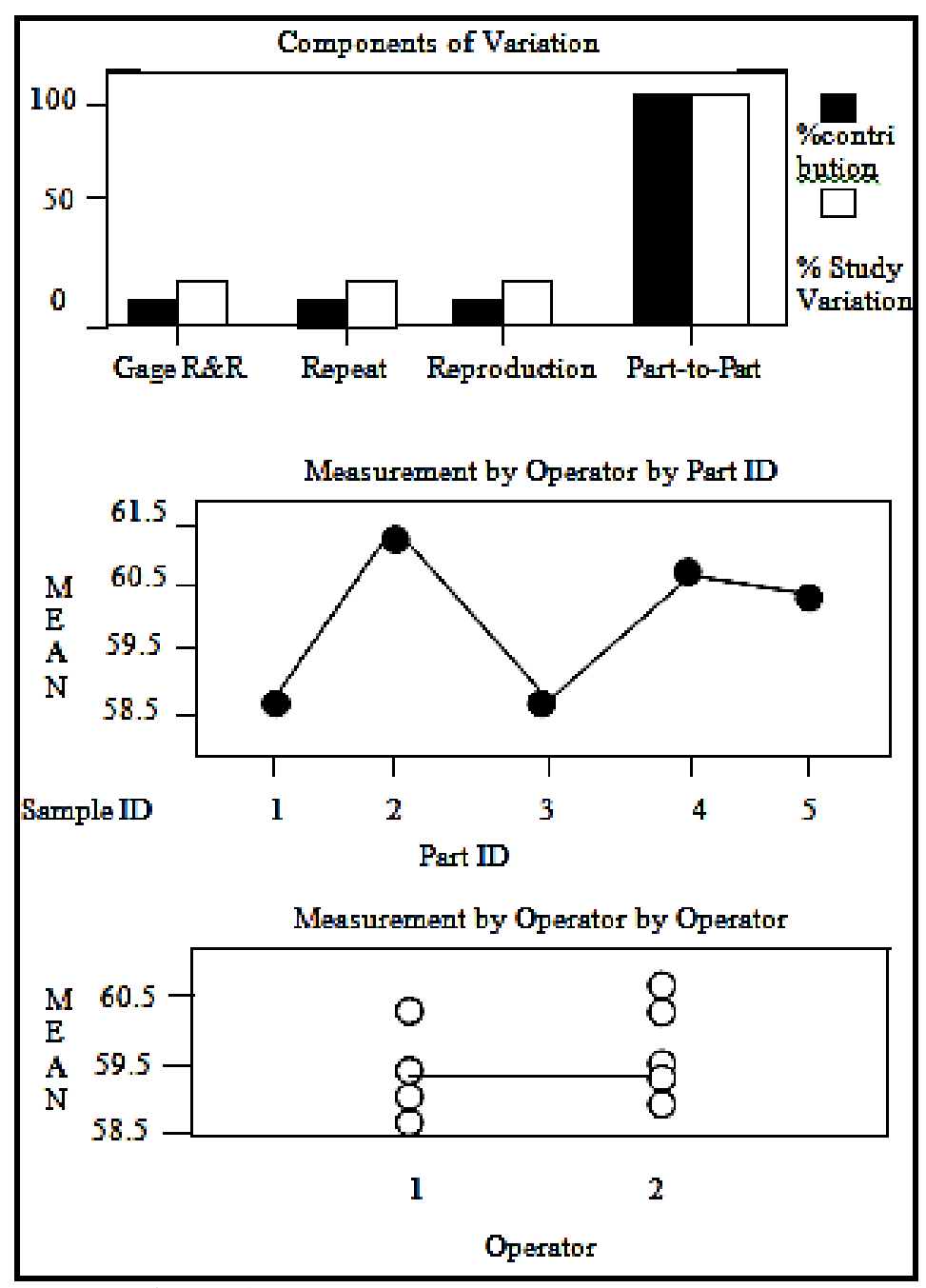

Figure 6. Gage R\&R (ANOVA) for Measurement

By the complete ANOVA study and Gages run chart and R\&R chart analysis shown in Figure 6 it is clear that percentage contribution of repeatability and reproducibility is very minimum and these are not making significant impact in variation data. Main cause of variation is found to be part to part variation.

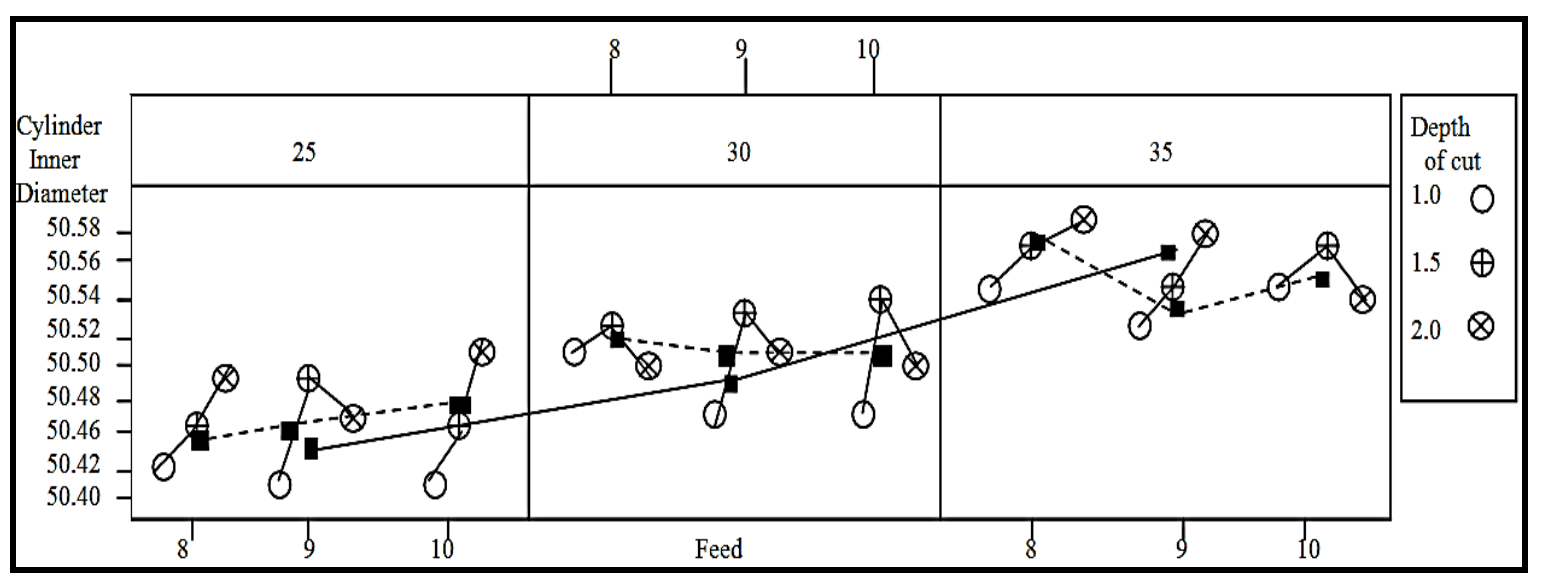

Figure 7. Multi-Vari Chart for Cylinder Inner Diameter by Depth of Cut-Tool Angle 
By Table 8 it is clear that Measurement Gage

\%contribution is $0.16<1$,

$\%$ study variation $=4.01<10 \%$,

$\%$ Tolerance $=6.71<10 \%$,

$\%$ Distinct categories $=35>10$

Hence the measurement system is acceptable and reliable for measurement purpose.

\section{Analyze Phase}

This phase focuses on analyzing the cause of defects defined in the before mentioned project phases. The first analysis was made on cylinder inner diameter. Table 9 shows One sample z test performed to check whether average inner cylinder diameter was 50.4512 or not.

Table 9. One-sample Z-Test of Cylinder inner diameter.

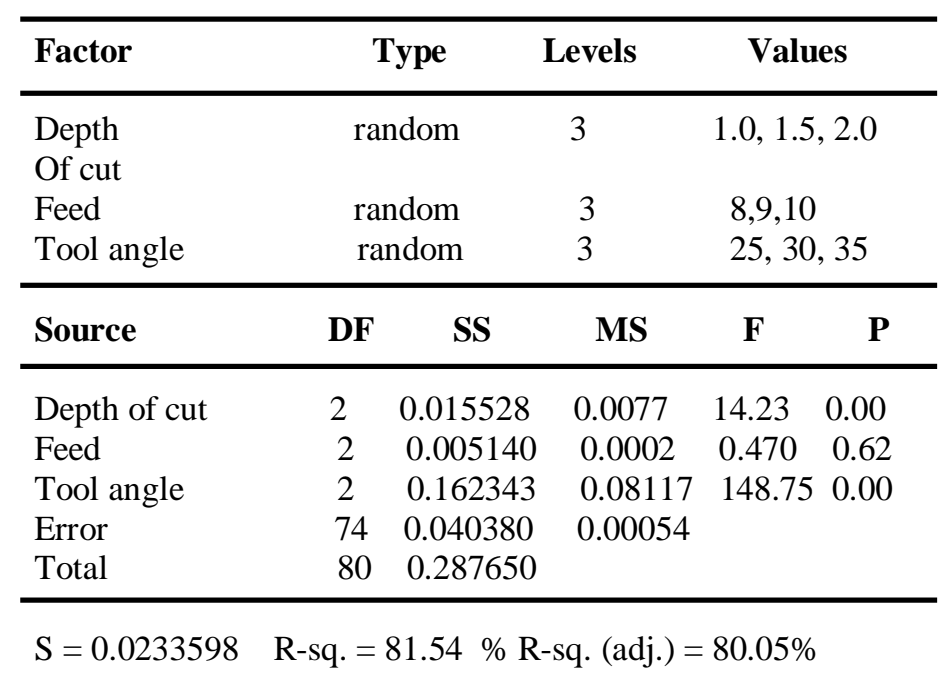

As given in Table 9 the P-Value of 1 is greater than alpha $=0.05$, the decision is not to reject null hypothesis. There is strong evidence that the average cylinder inner diameter is $50.4512 \mathrm{~mm}$. Next in the analyze phase is Multi-vari Analysis that was performed with three variables i.e. depth of cut with three settings 1.0,1.5,2.and tool angle with settings 25,30,35 degrees and feed rate with settings 8,9 and $10 \mathrm{~mm}$ per minute. Figure 7 shows the Analysis. The settings of variable that gave best responses are

- $\quad$ Depth of cut $=1 \mathrm{~mm}$

- $\quad$ Feed $=8 \mathrm{~mm} / \mathrm{min}$

- $\quad$ Tool angle $=35$ degrees

Next in the analyze phase is ANOVA performed on cylinder inner Diameter versus Depth of cut, Feed, Tool Angle. Exhibit Table 10 shows complete Analysis data.

Table 10. Analysis of Variance of Cylinder Inner Diameter

\begin{tabular}{|c|c|c|c|c|c|}
\hline $\begin{array}{l}\text { Factors } 2 \\
\text { Base runs } 9 \\
\text { Base blocks1 } \\
\text { Number of le }\end{array}$ & $\begin{array}{l}\text { Repli } \\
\text { total } \\
\text { Tota } \\
\text { els: } 3 \text {, }\end{array}$ & $\begin{array}{l}\text { icates: } \\
\text { runs } \\
\text { l Blocks } \\
3\end{array}$ & 3 & & \\
\hline $\begin{array}{l}\text { Factor } \\
\text { Depth of Cut } \\
\text { Tool angle }\end{array}$ & $\begin{array}{l}\mathrm{T} \\
\mathrm{fi} \\
\mathrm{f}\end{array}$ & $\begin{array}{l}\text { Type } \\
\text { ixed } \\
\text { ixed }\end{array}$ & $\begin{array}{c}\text { Levels } \\
3 \\
3\end{array}$ & $\begin{array}{l}\text { Valı } \\
1.0,1 . \\
25,30\end{array}$ & $\begin{array}{l}\text { ues } \\
5,2.0 \\
35\end{array}$ \\
\hline Source & DF & AdjSS & Adj MS & $\mathbf{F}$ & $\mathbf{P}$ \\
\hline $\begin{array}{l}\text { Depth of cut } \\
\text { Tool angle } \\
\text { Tool angle* } \\
\text { Depth of cut }\end{array}$ & $\begin{array}{l}2 \\
2 \\
4\end{array}$ & $\begin{array}{l}0.01111 \\
0.073563 \\
0.010148\end{array}$ & $\begin{array}{l}0.00555 \\
0.036781 \\
0.000253\end{array}$ & $\begin{array}{l}11.2 \\
74.11 \\
5.11\end{array}$ & $\begin{array}{l}0.001 \\
0.626 \\
0.006\end{array}$ \\
\hline
\end{tabular}




\begin{tabular}{llll} 
Error & 18 & 0.008933 & 0.000496 \\
Total & 26 & 0.103763 & \\
\hline $\mathrm{S}=0.0222777$ & R-sq. $=91.39 \%$ & R-sq. $(\mathrm{adj})=87.56 \%$
\end{tabular}

From data given in Table 10 it is clear that depth of cut and tool angle has significant effect over the response variable whereas feed has no significant effect. Hence these variables were considered in the improve phase for improving the response variables.

\section{Improve Phase}

Key findings from the analyze phase are that depth of cut and tool angle have the significant effect on the cylinder inner diameter. This was further analyzed by Multilevel factorial design in Table 11 in which cylinder inner diameter was tested against different levels of tool angle and depth of cut data obtained is given in Table 11

Table 11. Analysis of variance of Cylinder Inner Diameter using adjusted SS for tests

\begin{tabular}{|c|c|c|c|c|c|}
\hline $\begin{array}{l}\text { Factors } 2 \\
\text { Base runs } 9 \\
\text { Base blocks1 }\end{array}$ & $\begin{array}{l}\text { Repli } \\
\text { total } \\
\text { Total }\end{array}$ & $\begin{array}{l}\text { cates: } \\
\text { runs } \\
\text { l Blocks }\end{array}$ & & & \\
\hline Number of leve & $1 \mathrm{~s}: 3$, & & & & \\
\hline Factor & & ype & Levels & Valu & \\
\hline Depth of Cut & & xed & 3 & $1.0,1.5$ & $5,2.0$ \\
\hline Tool angle & & ixed & 3 & 25,30 & 35 \\
\hline Source & DF & AdjSS & Adj MS & $\mathbf{F}$ & $\mathbf{P}$ \\
\hline Depth of cut & 2 & 0.01111 & 0.00555 & 11.2 & 0.001 \\
\hline Tool angle & 2 & 0.073563 & 0.036781 & 74.11 & 0.626 \\
\hline Tool angle* & 4 & 0.010148 & 0.000253 & 5.11 & 0.006 \\
\hline Depth of cut & & & & & \\
\hline Error & 18 & 0.008933 & 0.000496 & & \\
\hline Total & 26 & 0.103763 & & & \\
\hline
\end{tabular}

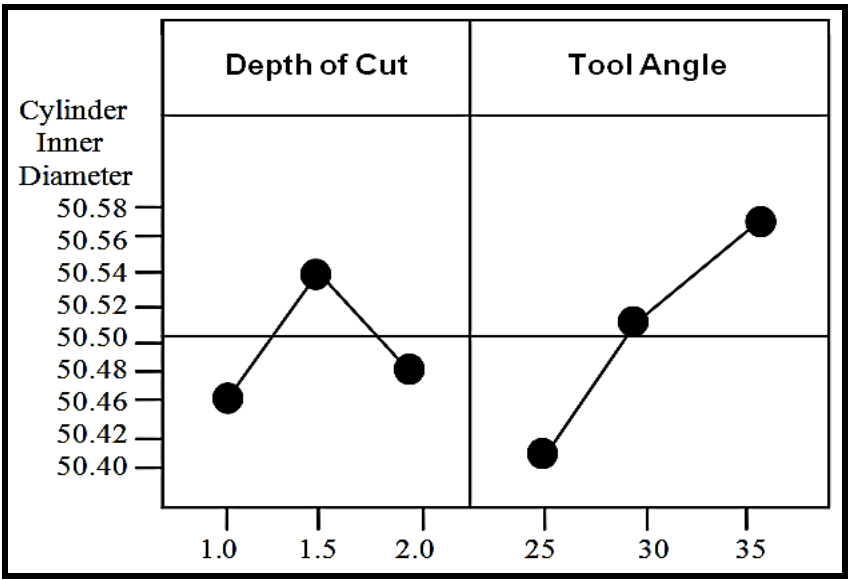

Figure 8. Main Effect Plots for Cylinder Inner Diameter 


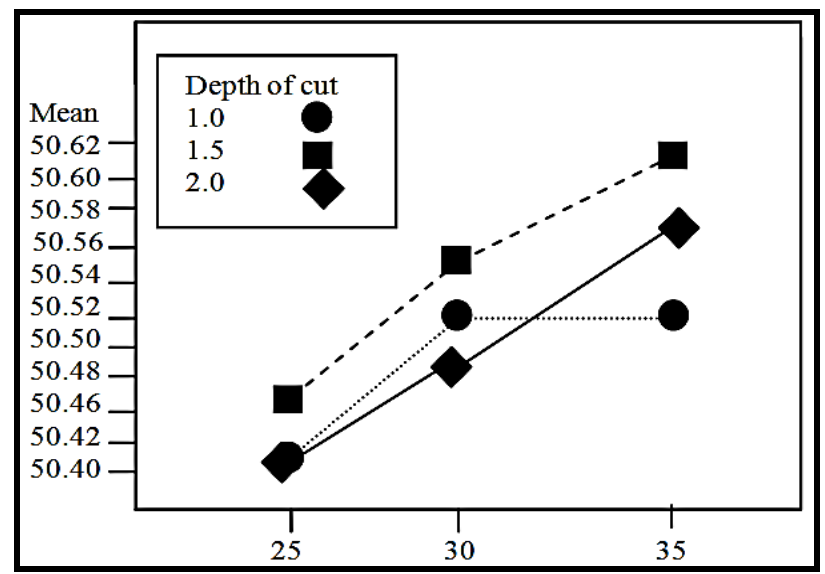

Figure 9. Interaction Plot (Data Means) for Cylinder Inner Diameter

Figure 8 and 9 show the main effect and interaction effect of depth of cut and tool angles. Form plots it is clear that depth of cut, and the interaction have significant effect on the response variable best results are obtained for the settings:

- $\quad$ Depth of cut $=1.5 \mathrm{~mm}$

- $\quad$ Tool angle $=30$ degrees

Regression analysis was also made to get the correlation between different response variables. The regression equation is given by equation 4 .

Cylinder inner diameter $=50.1+0.0058 *$ depth of cut $+0.126 *$ Tool angle

Table 12. Multiple Regression Analysis

\begin{tabular}{|c|c|c|c|c|c|}
\hline Predictor & \multicolumn{2}{|c|}{ Coef } & SE Coef & $\mathbf{T}$ & $\mathbf{P}$ \\
\hline Constant & \multicolumn{2}{|c|}{50.0974} & 0.042 & 1192.23 & 0.00 \\
\hline Depth of cut & \multicolumn{2}{|c|}{0.00583} & 0.01244 & \multirow{2}{*}{$\begin{array}{c}0.47 \\
10.12\end{array}$} & 0.642 \\
\hline Tool angle & \multicolumn{2}{|c|}{0.01258} & 0.001244 & & 0.000 \\
\hline \multicolumn{6}{|c|}{$\mathrm{S}=0.0304622 \quad \mathrm{R}$-sq. $=75.7 \%$} \\
\hline \multicolumn{6}{|c|}{ Table 13. Analysis of variance (ANOVA) } \\
\hline Source & DF & SS & MS & $\mathbf{F}$ & \\
\hline Regression & 2 & 0.095528 & 0.047764 & 51.30 .000 & \\
\hline Residual & 33 & 0.030622 & 0.000957 & & \\
\hline \multicolumn{6}{|l|}{ Error } \\
\hline Total & 35 & 0.125831 & & & \\
\hline
\end{tabular}

Using the multiple regression analysis in Table 12 and 13 it is clear that tool angle has significant effect on response variable whereas depth of cut has also an effect but not to significant. This is further confirmed by the best subset regression considering the maximum r-sq and minimum mallows c-p criteria, tool angle has the most effect and the interaction has the significant effect on the second number. The settings obtained from the analyze phase were implemented and data was monitored for some time.

\subsection{Analysis of the effect achieved after improvement}

Mean of cylinder inner diameter $=50.4972 \mathrm{~mm}$

Standard deviation of cylinder inner diameter $=0.032479 \mathrm{~mm}$ 


\subsubsection{Cumulative distribution function of sample taken}

Normal with mean $=50.4972 \mathrm{~mm}$

Sstandard deviation $=0.0324795 \mathrm{~mm}$

Cumulative distribution function

$\begin{array}{ll}\mathbf{X} & \mathbf{P}(\mathbf{X}<=\mathbf{x}) \\ 50.4 & 0.001383 \\ 50.6 & 0.999225\end{array}$

\subsubsection{Defective parts per million opportunities (DPPMO)}

Using formula given in equation 2, DPPMO is given as

$=(0.001383)+(1-0.999225) / 1000000$

$=2,158$

$=2.158 \%$

\subsubsection{Inverse Cumulative Distribution function}

Normal with mean $=0 \mathrm{~mm}$ and standard deviation $=1 \mathrm{~mm}$

$\begin{array}{cc}\mathbf{P}(\mathbf{X}<=\mathbf{x}) & \mathbf{x} \\ 0.002158 & -2.85409\end{array}$

Measure of distance from the mean of sample (Z-score) is calculated to be Z-score $=2.85409$ Process Capability index (Cpk) is calculated to be $\mathrm{Cpk}=2.85409 / 3=0.951363$

Using equation 3, Sigma capability for current process before improvement is calculated to be

$$
\begin{aligned}
\text { Sigma capability } & =\text { Z-score }+1.5 \\
& =2.85409+1.5 \\
& =4.354
\end{aligned}
$$

\subsection{Ensuring the sampling errors with test of Hypothesis}

To ensure that average cylinder inner diameter is 50.4972 or not a one sample $\mathrm{Z}$ test was performed. Exhibit 23 shows findings as follows:

- Ho: $\mu=50.4972$ (claim) and

- $\mathrm{H} 1: \mu \neq 50.4972$

Table 14. One-sample Z: Cylinder Iinner diameter

Test of mu $=50.4972$ vs. not $=50.4972$

The assumed standard deviation $=0.0324795$

\begin{tabular}{lllllllll} 
Variable & $\mathbf{N}$ & mean & stdev & SE Mean & $95 \%$ & $\mathbf{C I}$ & $\mathbf{Z}$ & $\mathbf{P}$ \\
\hline $\begin{array}{l}\text { Cylinder } \\
\text { inner D }\end{array}$ & 36 & 50.49 & 0.03 & 0.0054 & $\begin{array}{c}(50.48, \\
\text { 50.50) }\end{array}$ & 0.0 & 0.9
\end{tabular}

As given in Table 14 the P-value of 0.997 is greater than $\alpha=0.05$ the decision here is not to reject the null hypothesis. there is enough evidence to support the claim that the average cylinder inner diameter is 50.4972 .

\subsection{Testing difference between two Means (Large independent systems)}

- Ho: $\mu 1=\mu 2$ and

- $\mathrm{H} 1: \mu 1 \neq \mu 2$ (claim)

\subsubsection{Two sample T-Test and CI: Cylinder inner diameter}

Table 15 shows test results. 
Table 15. Two sample T-Test

\begin{tabular}{lcccc}
\hline & N & Mean & StDev & SEMean \\
\hline Cylinder Inner D & 50 & 50.4512 & 0.0708 & 0.010 \\
Cylinder Inner D & 36 & 50.4972 & 0.0325 & 0.0054 \\
Difference $=$ & & & \\
mu (cylinder inner Dia. Before Imp) - & (Cylinder Inner Dia. After Imp) \\
Estimate of difference : -0.046022 & \\
95\% CI for difference : $(-0.068718,-0.023326)$ \\
T-Test of difference $=0$ (vs. not =): T-Value $=-4.04$ \\
P-Value $=0.000$, DF $=73$.
\end{tabular}

In Table 15 the $\mathrm{P}$ value of 0.00 is less than alpha=0.05 so the decision is to reject the null hypothesis. There is enough evidence to support the claim that the two means are not equal. There is significant difference in cylinder inner diameter before and after process improvement.

\section{Control Phase}

Tables 16 and 17 show the overall control plan for the Project. Overall control plan includes three phases. First one is solution implementation Phase, in this phase settings of DMAIC Implementation phase were carried and observed for 2 months and were communicated to Project sponsor, process owner and Quality control head. Main objective of this phase is to monitor the process and decide whether the process is settled down and has absorbed the changes by giving the required results or it does not continue to give the improved results because of some other factors setting's that might be overlooked in the Improve Phase.

Next is training Phase which includes training of working staff as well as process owners and Quality Head to make them able to provide improved results if working conditions are slightly changed e.g. induction of new Machine in Assembly line or workers shift changes etc. Cost and benefits analysis is the last and project conclusion Phase, that was done after solution was Implemented and observed for 2 months.

Process Control plan is given in Table 17. It includes control of Pump Casings Inner diameter boring Control.

Machine used is turning and $100 \%$ inspection was carried on to observe this Process In detail. XBar and $\mathrm{R}$ charts were used to observe processes deviation and Mean shifts.

By observing XBar-R chart in Figure 10 it is clear that the process is well in control i.e. the variation with in groups is controlled. There are no points in X-bar chart that are more than 3 standard deviation away from Process Mean, also R chart shows that variation of process is well under control.

Table 16. Overall control plan

\begin{tabular}{|l|c|c|l|}
\hline S/No. & Description & Communicated to & \multicolumn{1}{c|}{ Approximate duration } \\
\hline 1. & $\begin{array}{c}\text { Solution } \\
\text { implementation } \\
\text { schedule }\end{array}$ & $\begin{array}{c}\text { Sponsor, } \\
\text { process owner, } \\
\text { Qc head }\end{array}$ & 02 months \\
\hline 2. & Training & Process owner, Qc head & 02 weeks \\
\hline 3. & $\begin{array}{c}\text { Cost and Benefits } \\
\text { Analysis }\end{array}$ & Sponsor & $\begin{array}{l}\text { Was carried Out after Implementing the solution and } \\
\text { running the process for 2 months }\end{array}$ \\
\hline
\end{tabular}

Table 17. Sample process control plan

\begin{tabular}{|c|c|c|c|c|c|c|}
\hline \multirow[t]{2}{*}{$\begin{array}{c}\text { Process/ } \\
\text { operation } \\
\text { description }\end{array}$} & \multirow[t]{2}{*}{ Machine } & \multicolumn{2}{|c|}{$\begin{array}{c}\text { Jigs, tools, } \\
\text { Fixtures for } \\
\text { manufacturing }\end{array}$} & \multicolumn{3}{|c|}{ Methods } \\
\hline & & Category & Number & $\begin{array}{l}\text { Spec. } \\
\text { limit }\end{array}$ & $\begin{array}{c}\text { Sample } \\
\text { size }\end{array}$ & $\begin{array}{l}\text { Control } \\
\text { method }\end{array}$ \\
\hline $\begin{array}{l}\text { Inner } \\
\text { Dia. } \\
\text { Boring }\end{array}$ & Turning & Jig & $\begin{array}{c}\text { T/jig/ } \\
002\end{array}$ & $\begin{array}{l}100 \% \\
\text { inspect } \\
\text { ion }\end{array}$ & 5 & $\begin{array}{c}\text { X-bar, } \\
\text { R-charts }\end{array}$ \\
\hline
\end{tabular}




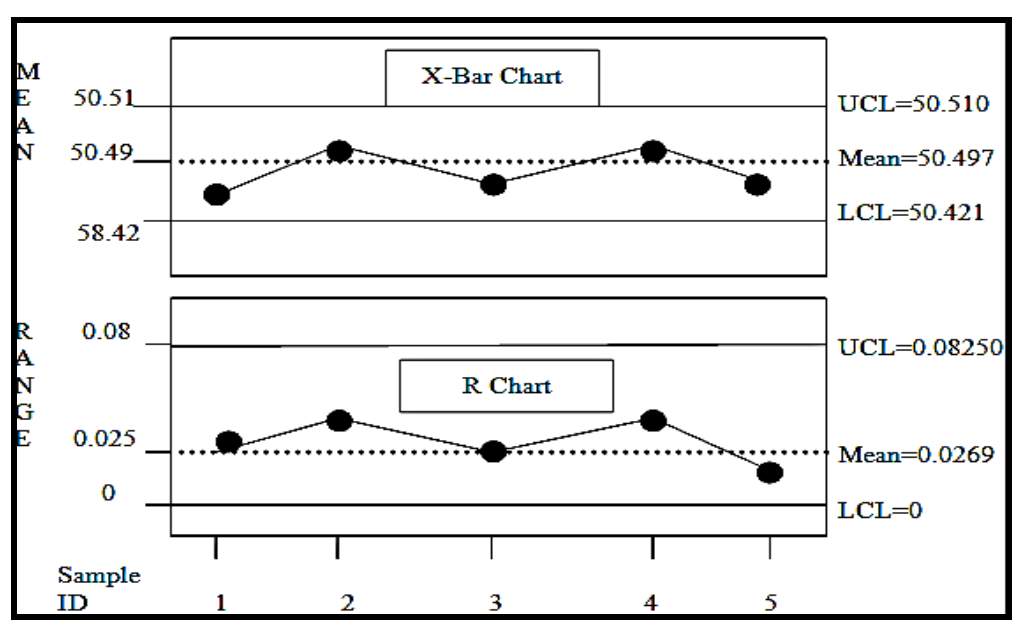

Fig.10. XBar-R chart of cylinder inner Diameter after improvement

\section{Conclusion}

Local pump casing manufacturing facility was receiving high defect rate due to which quality of the production lots was being effected and customer complaints had to be addressed. This was turning in to high financial loses to the company. An effective quality improvement technique called Six Sigma was decided to be implemented in the facility.

At this stage the defect rate was $25.27 \%$ with sigma capability of 2.16 . Pareto charts defined that chamber inner diameter defects were more than $71.4 \%$ of the total defects and was potential KPIV to be addressed. Further analyses cleared that depth of cut; feed rate and tool angle were contributing in defect rate. After carrying out detailed analysis of the process ,tool settings came out as main reason for this defect rate. feed rate had not significant effect as compared to depth of cut and tool angle. Best results were achieved at:

- $\quad$ Feed rate $=8 \mathrm{~mm} / \mathrm{min}$

- $\quad$ Depth of cut $=1.5 \mathrm{~mm}$

- Tool angle $=30$ degrees

Some jigs and fixture were required to achieve the above settings during production of rotor casings. These were designed and manufactured and then were Incorporated to reduce setups times and eliminate adjustments.

After getting the right settings from the analyze phase these settings were implemented and results achieved were in favor of good quality of products. Further results were monitored and controlled and finally defect rate observed is $2.158 \%$ with sigma capability of 4.354 .

\section{References}

[1]. Douglas, C. M. (2003). Introduction to Statistical Quality Control. New York, NY: John Wiley Publications.

[2]. Mahesh, B. P., Prabhuswamy, M. S. (2010). Process Variability Reduction through Statistical Process Control for Quality Improvement. International Journal for Quality research, 4(3), 1621-1635.

[3]. James, M. J., Mary, E. J. (2006). Lean and Six Sigma. LABMEDICINE, 37(3), 407-408.

[4]. John, J. F., Clark, W. A., San, C. A. (2006). Selecting Optimal Specification Limits. Quality Technology \& Quantitative Management, 3(2), 207-216.

[5]. Pleck, A., Vjica, H. (2009). An Application of six sigma in manufacturing company. Advances in production engineering and Management, 4, 243-254.

[6]. John, J. F. (2009). A unifying process capability metric. JIEM, 2(1), 48-59.

[7]. Mahesh, B. P., Prabhuswamy, M. S. (2010). Improvement of Quality Awareness using Six Sigma methodology for achieving higher CMMI Level. International journal of advance research in management, 1(1), 20-41.

[8]. Alessandro, L., Jiju, A., Alex, D. (2010). Lean six sigma in a call center: a case study. International Journal of Productivity and Performance Management, 59(8), 757-768.

[9]. Richard, J. L., Fugee, T., Lau, W. C. (2006). Supplier Selection Based on Process Capability and Price. Quality Engineering, 18, $123-129$.

[10]. Charles, R. Theodore, T. A. (2003). An Alternative Desirability Function for Achieving Six Sigma Quality. Quality and Reliability Engineering, 19, 227-240.

[11]. Chen, K. S., Huang, M. L., Li, R. K. (2001). Process capability analysis for an entire product. International Journal of Production Research, 39(17), 407-408.

[12]. Van, D. H., Edwin, R., Ion, S., Roxana, A. (2003). Control chart for Markov Dependent Sample Size. Quality Engineering, 12(4), 593-601.

[13]. Jeroen, D. M., Kit, C. B., Ronald, J. M. (2001). The multi vary chart: A systematic approach. Quality Engineering, 13(3), $437-439$. 


\section{Author's Biographies}

Faheem Yousaf is Masters Student at National University of Science and Technology in the School of Mechanical and Manufacturing Engineering. He received his Bachelor's degree in Industrial Engineering from University of Engineering and Technology Pakistan. His research interests include Quality Management, Operation Management and Manufacturing Engineering.

Shahid Ikramullah Butt, PhD, is Head of Mechanical Engineering at National University of Science and Technology in the School of Mechanical and Manufacturing Engineering. He has fifteen years of Industrial and Teaching Experience with different Organizations. Dr. Shahid received his Masters degree in Industrial Engineering from Mississippi State University and later on got his $\mathrm{PhD}$. in industrial and manufacturing engineering from Beijing Institute of technology, China.

Riaz Ahmad, $\mathrm{PhD}$, is acting as director research at National University of Science and Technology. He has blend of industry and academic experience spanning over 27 years. Besides being at senior management posts at university, he is supervising research and teaching undergraduate and post graduate courses at university. He has published number of research papers in international journals and conferences in field of Mechanical Engineering.

Contact: Faheem Yousaf, School Of Mechanical and Manufacturing Engineering, National University of Science and Technology, Islamabad, Pakistan, Engr_faheem37@yahoomail.com. 